\title{
DIALOGUE WITH THE MASTER: EARLY SHİ'A ENCOUNTERS WITH AKBARĪAN MYSTICISM $^{1}$
}

\author{
Leila Chamankhah \\ University of Dayton, Ohio, United States \\ E-mail:1.chamankhah@gmail.com
}

\begin{abstract}
Muhyy al-Dīn Ibn 'Arabī's theoretical mysticism has been the subject of lively discussion among Iranian Sufis since they first encountered it in the seventh century. 'Abdul Razzāq Kāshānī was the pioneer and forerunner of the debate, followed by reading and interpreting al-Shaykh alAkbar's key texts, particularly Fușuss al-Hikam (Bezels of Wisdom) by future generations of Shī'i scholars. Along with commentaries and glosses on his works, every element of ibn 'Arabì's mysticism, from his theory of the oneness of existence (waḥdat al-wujūd) to his doctrines of nubuwwa, wilaya, and khatm al-wilaya, was accepted by his Shi's peers, incorporated into their context and adjusted to Shī'a doctrinal platform. This process of internalization and amalgamation was so complete that after seven centuries, it is difficult, if not impossible, to distinguish between Ibn 'Arabì's theory of waḅdat al-wujūd, or his doctrines of wilaya and khatm al-wilaya and those of his Shī'i readers. To have a clearer picture of the philosophical and mystical activities and interests of Shī's scholars in Iran under Ilkhanids (12561353), I examined the intellectual and historical contexts of seventh century Iran. The findings of my research are indicative of the contribution of mystics such as 'Abdul Razzāq Kāshānī to both the school of Ibn 'Arabī in general and of Șadr al-Dīn al-Qūnawī in particular on the one hand, and to the correlation between Sufism and Shīism on the other. What I call the 'Shī'itization of Akbarian Mysticism' started with Kāshānī and can be regarded as a new chapter in the history of Iranian Sufism.
\end{abstract}

Keywords: Theoretical mysticism, Ibn 'Arabī, 'Abdul Razzāq Kāshānī, Wilāya, Khatm al-Wilāya, Sufism, Shī'‘̄sm.

1 The author is grateful to Professor Liyakat Takim of McMaster University in Hamilton, Canada, for reading and commenting on the article before publication. 


\section{Introduction}

I will provide a general picture or idea of intellectual activities in Iran prior to the first encounter of Sufis with the 'irfän of Ibn 'Arabī in the second half of the seventh century. Ibn 'Arabi had a profound impact on a number of Sufis with Shīa inclination, although the reason(s) why it was important for them to analyze him from a Shi'a perspective has yet to be studied. It is interesting to note that Ibn 'Arabî's relationship with his Shī'i exponents was deeper and more sophisticated than mere interpretation, and in fact, contains 'adjustment' and 'dissemination'. Akbarian mysticism in these figures' hands, whom I prefer to call Shīa-minded Sufis, surpassed its original construct and transformed into a new configuration that, while maintaining similarities with and being influenced by it, should be treated as an independent philosophical system. 'Abd al-Razzāq Kāshānī, 'Alā’ u-Dawlah Simnānī (d. 736 H/1336), Sayyid Haydar Āmulī (d. 787 H/1385), and the Azerbaijāni Sufi and poet, Shaykh Mahmūd Shabistarī ${ }^{2}$ (d. $740 \mathrm{H} / 1340$ ) of the seventh and eighth centuries, to mention a few, are notable exponents in this regard.

It is possible to identify two reasons for Iranian Sufis's interest in reading and interpreting Ibn 'Arabî's mysticism in a Shī'a style. First, Twelver Shī'ism contains the same elements as Akbarian mysticism, albeit existing in a more primitive mode of a "raw mysticity", which needs to be fertilized and inseminated when the necessary catalyst is available.

Several resources such as the office of the imamate as the cornerstone of Shīism with the personality of the imàm as the living exemplar at its heart, the doctrine of mabdawiyya, the concept of divine knowledge and the allegorical interpretation of religious duties and of

2 Shabistarî's brightness of mind is revealed by his comprehension of the complexities of wabdat al-wujüd and his skills in adding to Ibn 'Arabì's intellectual system. He could be regarded as the representative of a brand of mysticism whose main characteristic was pouring 'irfän into Persian literature as a means of expounding and illuminating it. For Shabistarī, the rich tradition of Persian literature was a framework through which the Akbarian mysticism's intricacies were expressed more fully. In his magnum opus Gulshan-i Rãz (the Rose Garden of Mystery), which is written in the form of an ode (mathnawr), Shabistari discusses the main 'irfäni/ kalämi ideas of the First Emanated, the state of completeness or totality (maqäm-i jämi'), as well as the theory of the Perfect Man, of milayya and nubunwa. See Mahmūd b. 'Abd al-Karīm Shabistarī, Gulshan-i Rāa (the Rose Garden of Mystery), Muhạmmad Hịāṣīyān (ed), (Kerman: Khadamāt-i Farhangī-ya Kerman, 2003), 16. 
the Book, nourished this mysticity. All of them had the potential for mystical interpretations, thanks to the scholarly works of Mohammad Ali Amir-Moezzi, who provides us with abundant information about classical Shīism, as well as the role of these elements in creating a Shi'a identity in its formative period. ${ }^{3}$ One can add to these sources supplications, salutations, and psalms, which always occupied a central place in Twelver culture. ${ }^{4}$ Kāmil Muṣtafā Al-Shaybī, Seyyed Hossein Nasr, and Shahrām Pāzūkī ${ }^{5}$ who considerably contributed to the existing scholarship on the correlation between Shīism and Sufism in general, and the reception of Akbarian mysticism among Shi' 1 i scholars in particular, ${ }^{6}$ studied the role of the abovementioned factors in this union but neglected to discuss the potential of supplications in preparing the background for such a relationship.

Examination of the content of these prayers, which were gathered over centuries, as well as their veracity, is beyond the scope of this research. Therefore, I only briefly indicate the two main themes of this trio (supplications, salutations, and psalms); i.e., tawhid

3 From among Amir-Moezzi's books, I am particularly interested in these two: Mohammad Ali Amir-Moezzi, The Divine Guide in Early Shiism: the Sources of Esotericism in Islam, translated into English by David Streight (New York: State University of New York Press, 1994); Mohammad Ali Amir-Moezzi, The Spirituality of Shii Islam: Beliefs and Practices (London and New York: I. B. Tauris Publisher, 2011).

4 The main two messages of this trio (supplications, salutations, and psalms), are tawhid and servitude (lit. 'ubüdiyya), with a special emphasis on safeguarding believers from the hardships of life and death. The allegory of bisn (lit. castle) and/or siläh (lit. weapon), which shelter believers or arm them to overcome difficulties is a recurring theme in the Twelvers' prayer culture. The most prominent example is the wellknown Jawshan al-Kabir and Jawshan al-Saghir (Major and Minor Armor, respectively), which has taken its name from it.

5 Shahrām Pāzūkī, Jāmi al-Asrār: Jāmi bayn Tașawnuf wa Tashayu', in Muștafāa Azmāyish (ed.), Irfän-i Iran (Iranian Mysticism), No. 7 (Tehran: Haqīqat Publication, 1379 shamsi), 78-103.

6 Seyyed Hossein Nasr, Sufi Essays (New York: Schocken Books, 1977); Kāmil Muștafā al-Shaybī, al-Silah bayn al-Tasannuf wa al-Tashayu', 2 volumes, 3rd edition (Beirut: Dār al-Andalus, 1982); Kāmil Muștafā al-Shaybī, Sufism and Shì ı̀sm (Surbiton: LAAM, 1991). And many other younger scholars who studied Shīissm and Sufism from this perspective. One of them is Rebecca Masterton, whose research delves into the spiritual authority of awliy a and its similarities in Sufism and Shicrsm. See Rebecca Masterton, "A Comparative Exploration of the Spiritual Authority of the Awliya' in the Shi' $i$ and Sufi Traditions", American Journal of Islamic Social Sciences, Vol. 32, No. 1 (2015), 49-74. 
and servitude (lit. 'ubüdiyya), which indirectly impacted the correlation between Shīism and Sufism. On the other hand, since these supplications had the imprint of the imams - as both narrator and teacher-as well as their teachings, the narrator/imam is the living exemplar and the ideal type of 'ubüdiyya and zubd, which are also the two main motifs of Sufism in its formative period. ${ }^{7}$ These common elements in both Sufism and the supplication tradition pursue one aim: they concern themselves with the activation and cultivation of the soul and of the Self (nafs) that seem to be neglected outside the realm of Sufi and Shī'a spirituality. ${ }^{8}$

Our analysis is confirmed via Michael Ebstein's discussion of the Shi' group of ghulät's impact on several Akbarian themes such as incarnation (bulūl) and imam as a divine manifestation. These ideas, which originally emerged in the ghulat group of Kufa around the midsecond/eight century, resurfaced later in Ismä'tì circles and finally were endorsed and crystalized by Ibn 'Arabī as zubür and tajalli. Pertinent to this is the binary of divine organs of man and human organs of God (wali/good servant is the organ of God and vice versa), as well as the doctrine of the Perfect Man, both with their bold Shi's coloring. Ebstein points to the wilayat al-takwiniya of the office of khiläfa of the Perfect Man, which unlike the elitist Shí'a worldview that limits this right only and exclusively to the imams, embraces humanity and even the whole creation too. ${ }^{9}$ With regard to Ebstein's analysis, there was a unique exchange of ideas between the Shí ${ }^{\top} a$ extremists of the mid-second century on the one hand and Ibn 'Arabî's mysticism (via the intermediary role of the Ismā'îli circles such as Ikhwān al-Ṣafā) on the other. These exchanges started with the infiltration of a few ghulät ideas to the irfän of Ibn 'Arabī, which were later refined and developed by him and finally returned to its Shi'a milieu in the seventh century.

\footnotetext{
7 Ahmet T. Karamustafa, Sufism: the Formative Period (Edinburgh: Edinburgh University Press, 2007).

8 Bernd Radtke has discussed the importance of this goal in Sufism in light of "the impress of enlightenment and science". See Bernd Radtke, "Between Projection and Suppression: Some Considerations Concerning the Study of Sufism", in Frederick De Jong (ed.), Shi'a Islam, Sects and Sufism, Historical Dimensions, Religious Practice, and Methodological Considerations (Utrecht: Publications of the M. Th. Houtsma Stichting, 1992), 70-82.

9 Michael Ebstein, "The Organs of God: Hadīth al-Nawāfil in Classical Islamic Mysticism", Journal of the American Oriental Society, Vol. 138, No. 2 (2018), 13-18.
} 
Second, and from a theological perspective, the Akbarian theories of wilaya and khatm al-wilaya, as well as that of the Perfect Man and wahdat al-wujüd, seemed revolutionary and sometimes even alien to the Shī'a ethos, but accommodating jarring sets of ideas within the moderate framework of Twelver Shīism was not unprecedented among Shī'î scholars. Al-Shaybī shows how the extremist beliefs in the Abbasid era-and particularly those of Hishām b. Hakam (d. 199 Hegira/815-816)—were refined from their unconventional redundancy and became incorporated into the mainstream Shî'ism of the second century. ${ }^{10}$ Furthermore, as Amir-Moezzi discusses, after the fourth century (tenth century CE) and as a result of the establishment of the Buwaihids (also Buyids, $320 \mathrm{H} / 932$ - 447 $\mathrm{H} / 1055)$ and due to some political considerations, Twelvers tended to highlight the more "rational" (i.e., juridical and kalami) dimensions of their creed at the expense of its esoteric aspect. History repeated itself when in the mid-seventh/thirteenth century, Ibn 'Arabli's mysticism underwent the same experience and its different doctrines, including that of wilaya, the Perfect Man and wahbdat al-wujüd, were customized according to the Shía creed. Therefore, and from this perspective, it is no exaggeration to say that the seventh century should also be called 'the Shî'a century'.

\section{Contextualizing Iranian Sufism: A Case Study of 'Abdul Razzāq Kāshānī}

'Abdul Razzāq Kāshānīi1 in his Majmū'ah Rasằil wa Musannafät (Collected Treatises and Writings), recounts that the first time scholarly circles in Shiraz became familiar with Fususs dates back to $655 \mathrm{H} / 1257,{ }^{12}$ when two of his masters in Sufism, ${ }^{13}$ Shaykh Dịyā al-

\footnotetext{
10 al-Shaybī, al-Silah bayn al-Tasannuf wa al-Tashayu', Vol. 1, 150-151.

${ }^{11}$ For Kāshānì's position in the line of immediate followers and disseminators of Ibn 'Arabī, staring from Ṣadr al-Dīn Qūnawì (d. 673 H/1274) and ending in Dāwūd Qayșarī (d. 751 H/1350), See William Chittick, "The Five Divine Presences: From al-Qūnawī to al-Qayșarì’, The Muslim World, Vol 72, Issue 2 (April 1982), 107-108.

$12 \mathrm{Ibn}$ 'Arabī had died seventeen years earlier in 638.

13 As 'Abd al-Hussein Zarrīnkūb ascertains, Kāshānì's masters were all Suhrawardī Sufis, and he had Suhrawardi training in Sufism, and that is why he cannot be regarded as a simple follower and commentator of Ibn 'Arabī. He in fact merged Akbarian mysticism with the Suhrawardī teachings. See 'Abdul Hussein Zarrīnkūb, Dunbäla-yi Justujü dar Tasawnuf-i Iran (Sequel to Inquiries into Persian Sufism), $5^{\text {th }}$ edition (Tehran: Amīr Kabīr Publication, 2001), 130-131.
} 
Dīn Abū al-Ḥasan al-Shīrāzì (d. $70 / 1306)^{14}$ and Shaykh Shams al-Dīn Muhammad b. Aḥmad al-Ḥakīm Kīshī (d. 694 H/1295), had difficulty finding an expert in Shiraz with whom they could discuss tawhid, or who could answer their questions regarding the subject. Quoting Kīshī, Kāshānī writes:

"... and at that time, there was no one in Shiraz with whom I could discuss tawhầ, and Shaykh Dịyāa al-Dīn Abū Hạasan did not have enough knowledge about it, and I [myself] was also perplexed, until Fusüs reached here. ${ }^{15}$

In consideration of the above-mentioned quotation as well as the time of the completion of the Fususs in $627 \mathrm{H} / 1229,{ }^{16}$ it seems that it only took twenty-eight years for the Fusus to reach Shiraz and become accessible to Kāshānī's masters who lived during the Ilkhanid dynasty. We know much about the intellectual life of the seventh century Iran under the Mongol rule. As Lambton, Pfeiffer, AmitaiPreiss, and al-Shaybī, ${ }^{17}$ among others have discussed, while Shi ${ }^{i} i s m$ was an exception, Sunnism was the rule, and Sunni Sufism was particularly popular and vibrant. Ostensibly, the decline of the Abbasid caliphate, the impartiality of the Mongols in religious affairs, and the release of Sufism from Sunnism contributed to a rise in the status of Sufism. The two main Sufi silsilas of Subrawardìya (to which Kāshānī was affiliated) and Kubrawiya, as well as lesser tariqah, such as Käziriuniya (also Ishäquiya) ${ }^{18}$ and Rushdìya, were active and prevalent at that time. ${ }^{19}$

${ }_{14}$ With the full name of Naṣir al-Dīn Abū Hạamid Maḥmūd b. al-Imām Dịiyā al-Dīn Abū al-Hasan Mas'ūd b. Mạ̣mūd al-Shīrāzī. For the complete list of the names of Kāshānì's masters, I consulted with Fatemeh Tayefeh's doctoral thesis entitled "Concept of Chivalry (Futumwah) According to 'Abdul Razzāq Kāshānī: Analysis on His Tubfat al-Ikhwān fì Khasă'is al-Fityān (Brethren Trove in Chivalry)" (Academy of Islamic Studies--University of Malaya, 2015).

15 Unfortunately, I did not have direct access to Majmü'a Rasä'il wa Musannafät and my correspondence with the publisher was inconclusive.

${ }^{16}$ Kamāl al-Dīn 'Abdul Razzāq Kāshānī, Sharḥ-i Fusūs al-Hikeam (Commentary on the Fuṣuss al-Hikam) Majīd Hādīzādih (ed.) (Tehran: Anjuman-i Āthār wa Mafākhir-i Farhangī, 2004), 44.

${ }^{17}$ al-Shaybī, Sufism and Shï ism.

18 The silsila was founded by Shaykh Ibrāhīm Shahrīyār Kāzirūnī (d. d. 426/1035), A. K. S. Lambton, FĀRS iii. History in the Islamic Period, Encyclopedia Iranica, 2012. http://www.iranicaonline.org/articles/fars-iii, last accessed 11/20/18.

19 'Abdul Hussein Zarrīnkūb in Dunbāla-yi Justujū dar Tasawnuf Iran) in his discussion of Iranian Sufism indirectly indicates the popularity of "Sunni mysticism", though he never mentions the term and only refer to it as "Șüfiya-yi Iran" (lit. Iranian 
Not only were they popular, but they were also attached to the court. It seems that the Ilkhanid policy was to invest in moderate and established mystics; figures such as Safī al-Dīn Ardibīlī (735 $\mathrm{H} / 1334),{ }^{20}$ the disciple of Shaykh Zāhid Gīlānī, or the Kubrawī Shaykh, 'Alā' u-Dawlah Simnānī (d. 736 H/1336), rather than radical and ghäli Sufis who seemed to be troublesome for the political stability of their territory. It is beyond the objectives of this paper to investigate the reasons for this policy. I can briefly say that by attaching themselves to moderate Sufis and recruiting them into their system, Mongols wanted to use their capabilities, including their knowledge and popularity, as valuable sources of legitimacy.

The Mongols' attachment to moderate mystics was a policy that had been started by Abū Sa ‘īd's si ancestors, Arghūn (d. 695 H/1316) and his son Uljeitū (d. $690 \mathrm{H} / 1291)$. The abovementioned 'Alā' uDawlah Simnānī, who was in the official service of Arghūn as well as Safí al-Dīn, could successfully restrain many of the Mongols "from molesting the people". ${ }^{22}$ As Al-Shaybī ascertains, this policy was based on the mutual need of the Mongols and the Sufis. The Mongols "needed a group of people who would calm the people and react towards the Mongol invasion in accordance with the Sufi doctrine of satisfaction and resignation". ${ }^{23}$ Non-moderate Sufism, such as Nürbakbshìyya, Hurüfìya, Musha'sha'ìyya, and Sarbidàr, with chiliastic orientation and ghäli colorations, were active and operating, ${ }^{24}$ and like the Abbasid era, had characteristics which resembled the Shi'a extremist movements. ${ }^{25}$ The collapse of the Abbasids was beneficial for moderate Shīissm as well, which was slowly but gradually rising to

Sufism), See Zarrīnkūb, Dunbāla-yi Justujū, 127; Judith Pfeiffer, "Conversion Versions: Sultan Öljeytü’s Conversion to Shicism (709/1309) in Muslim Narrative Sources", Mongolian Studies, Vol. 22 (1999), 10, Reuven Amitai-Preiss, "Sufis and Shamans: Some Remarks on the Islamization of the Monglos in the Ilkhanate", Journal of the Economic and Social History of the Orient (JESHO), Leiden, Vol. 42, No. 1 (1999); and al-Shaybī, Sufism and Shìism, 112-115.

20 Amitai-Preiss, Sufis and Shamans, 35.

${ }^{21}$ Abū Sa ‘̄ìd Bahādur Khān (d. 736 H/1335).

22 Mustawfī in Amitai-Preiss, Sufis and Shamans, 32, 35-36.

23 al-Shaybī, Sufism and Shìism, 112.

24 William F. Tucker, the Kufan Ghulat and Millenarian (Mabdist) Movements in MongolTurkemen Iran, in Unity in Diversity: Mysticism, Messianism, and the Construction of Religious Authority in Islam, Orkhan Mir-Kasimov (ed.) (Leiden: Brill, 2014), 177-194.

25 al-Shaybī, Sufism and Shi ${ }^{\circ} \mathrm{ism}, 56$. 
prominence and recognition, due both to the conversion of a number of Ilkhanid Khāns, such as Ghāzān, to Shīîssm, and the adoption of a moderate attitude by Twelvers. ${ }^{26}$

Tucker emphasizes that Twelvers, compared with extremist Shī'as who represented millenarian fervor, showed a "relatively moderate and frequently quiescent" attitude ${ }^{27}$ because of their sociopolitical weaknesses. ${ }^{28}$ Nevertheless, despite this passivity in politics, Twelver (or moderate) Shīissm was not only gradually receiving social popularity and acceptance, but also Shí a elements were infiltrating the Sufi system, and sometimes became a replacement for it. Mahmūd Taqī Zādih Dāwarī observes how the Sufi dhiker recitation sessions became replaced by Āshürā and lamentation for imām Hussayn. ${ }^{29}$ Developments such as this prepared groundwork for the emergence of the Safawids, whose era was a landmark of the free reign of popular Shīism to a variety of expressions. ${ }^{30}$

Earlier, I mentioned Kāshānı̀s quote about his masters' difficulty in finding an expert in Shiraz with whom to discuss tawhid until the Fususs reached the city and became accessible to them. Ostensibly, the Fusüs had gained popularity in Shiraz's Sufi circles almost immediately after its composition. ${ }^{31}$ So, too, did the theory of

\footnotetext{
${ }^{26}$ Ibid., 110-112, 139.

27 Tucker, the Kufan Ghulat, 182.
}

28 Amir-Moezzi believes that prior to the establishment of the Buyid dynasty, Shīism was esoteric and it was only after the Buyids that this differentiation between esoteric and moderate Shīissm (here kalami/juridical) started. He also is reluctant to use the term "extremist" because what looked to be "extremism" in the post-Buyid era was not only the esoteric narrative of Shīism in pre-Buyid era, but also the sole tendency among Twelvers. In other words, Shīism was esotericism and vice versa. Therefore, the term "extremist", according to Amir-Moezzi, is insufficient and does not reflect the reality of historical developments.

${ }^{29}$ Maḥmūd Taqī Zādih Dāwarī, Sunat-i 'Azādārī wa Manqibat Khānì dar Tärikh-i Shì'ayi Emàmìy (The Lamentation Tradition and Mourning in the History of the Imāmi Shìism) (Qum: Shī'a Shināsī, 1386 Shamsi).

${ }^{30}$ Momen's assessment of the "free reign" of Shīism not only explains the socioreligious developments of the Safawid era, but also sheds light on the pre-Safawid developments as well. He observes how "the devotion of ordinary people towards the Sufi saints, which had been a major factor in popular religiosity in previous centuries, was gradually transferred to the Shii Imams, who now became the spiritual intermediaries and intercessors of the masses". See Moojan Momen, Shic Islam: A Beginner's Guide (London: Oneworld, 2016), 147.

31 As Caner Dagli explains, Fusūs "was an important starting point for the centuries of philosophical elaboration" which had begun by Qūnawī and reached its 
waḥdat al-wujüd, which "was in ultimate widespread" by Ibn "Arabī's disciples. ${ }^{32}$ Tayefeh's analysis is similar to that of Dagli who ascertains that by the time of Kāshānī, Ibn 'Arabî̀s mysticism had "already started to become a kind of meta-order, not itself providing spiritual initiation, but existing as a special dimension within existing orders". ${ }^{33}$

The teachings of Ibn 'Arabī facilitated the shaping of the three intellectual tendencies in Muslim societies, including the philosophical school of Șadr al-Dīn al-Qūnawī (with figures such as Kāshānī, the aforementioned Haydar Āmulī and 'Abd al-Karīm al-jīlì (d. 826/1424 ?) as its members), the mystical poetry of Nūr al-Dīn 'Abd al-Rahmān Jāmī (d. 871/1492), and Fakhr al-Dīn 'Īrāqī (d. 688/1289), and finally the philosophy of Mullā Șadrā (d. 1045/1635-36?) and his successors (known as hikma/bikmat discourse). ${ }^{34}$ At the beginning of its development, the first school had "extremely close interaction",35 with "the separate intellectual traditions of Avicennan falsafa" 36 and later kalam ${ }^{37}$ and it is due to this close contact that Morris rightly believes that Ta'milät Qur'ān-i Hakim of Kāshānī, to which I will return shortly, is not so much a ta'wil in its Sufi meaning and usage, but is rather "based on elements from both Ibn 'Arabî's writings and the prevalent Avicennan school of philosophy in which Kāshānī himself was originally trained". 38

culmination at the time of Dāwūd al-Qayșarī. Besides, "it was precisely because it was brief, difficult, and controversial that the Fusüs became a kind of template for the philosophical speculations and elaborations of his school". See Caner K. Dagli, Ibn 'Arabi and Islamic Intellectual Culture: from Mysticism to Philosophy (London and New York: Routledge Sufi Series, 2016), 5. Kamāl al-Dīn 'Abdul Razzāq Kāshānī, Sharh-i Fusūss al-Hịikam, Maj̄̄l Hādīzādih (ed.) (Tehran: Anjuman-i Āthār wa Mafākhir-i Farhangī, 1383 shamsi), 46-47.

32 Tayefeh, "Concept of Chivalry (Futumwah) According to 'Abdul Razzāq Kāshānì”, 30.

33 Zarrīnkūb indicates that the encounter of Iranian Sufis with Akbarian mysticism could not have been easy and comfortable. See Zarrīnkūb, Dunbāla-yi Justujū, 127. Though he does not bring any evidence to prove it. Dagli, Ibn 'Arabi and Islamic Intellectual Culture, , 105.

34 James W. Morris, "Ibn Arabî and His Interpreters, Part II-B", Journal of American Oriental Society (JAOS), Vol. 107 (1987), 101.

35 James W. Morris, "Ibn Arabî and His Interpreters, Part II-A", Journal of American Oriental Society (JAOS), Vol. 106 (1986), 33.

36 Ibid., 33.

37 Ibid.

38 Morris, “Ibn Arabî̀" 1987, 3-4. 
Regarding Kāshānî’s contribution to the first school, I should mention "his eminence in the field" 39 as well as his significant role in publicizing Akbarian mysticism in the Ilkhanid court. Through the lens of his commentary on the Fusuis, the later generations of Sufis familiarized themselves with the highly sophisticated and erudite metaphysics of Ibn "Arabī. So, his role was that of "formalization" of the language and the technical terms and concepts of the Fuṣus ș ${ }^{40}$ by putting together three lexicons (among many other writings), which eventually helped novices to navigate their way around the oftenbumpy terrain of the intricacies of Ibn 'Arabì's terminology. On the other hand, Kāshānì's "guidebook style approach for autodidacts", 41 for those who were excluded from law colleges and madrasas, was useful for "public debates that were enduringly popular at the riyal Mongol court". ${ }^{42}$

Pertinent to Kāshānì's intellectual genealogy as well as his contribution to the legacy he inherited from the past, is his "legal and theological affiliation", ${ }^{43}$ which, according to Lala, "seems premature, as it is not even known whether he was Sunni or Shicite". "Several scholars have shed light on it and considered him a Shici Sufi. ${ }^{45}$ Others simply call him an Iranian Sufi, ${ }^{46}$ and Zarrīnkūb and Dagli believe that because of his Suhrawardī masters and training, he cannot be Shî ${ }^{-1} .{ }^{47}$ Lala also believes that Kāshānìs respect for the abl al-bayt and his visits to Najaf and Karbala should not make us conclude that he was a Shi'a, because pilgrimage to the tombs of Ali and his sons is "de

\footnotetext{
${ }^{39}$ Ismail Lala, Knowing God: Ibn 'Arabi and 'Abd al-Razzāq al-Qäshänì's Metaphysics of the Divine (Leiden and Boston: Brill, 2019), 28.

${ }^{40}$ Lala, Knowing God, 28-31.

${ }^{41}$ Ibid., 31.

42 Ibid.

${ }^{43}$ Ibid., 22.

44 Ibid.

${ }^{45}$ Nasr, Sufi Essays, 116; Fātemeh 'Alāqah, "Murürū bar Fityān wa Futuwwat Nāmihāa: A Review on Chivalrous and Books of Chivalry", Farhang, No. 25-26 (Spring and Summer 1377 Shamsī/1999), 11; Alī Ashraf Imāmī, "Nigāhī bi Iṣtilāhāat-i Ṣūfìya-i Shaykh 'Abdul Razzāq Kāshānī: A Glimpse at Kāshānī’s Lexicon of the Sufi Terminology", Majalla-yi Dānishkada-yi 'Ulüm-i Insānì, No. 1 (Spring 1381 Shamsī/2001), 62-63.

46 Tayefeh, "Concept of Chivalry (Futumwah)", 36.

47 Zarrīnkūb, Dunbāla-yi Justujūu, 127-133; Dagli, Ibn 'Arabi and Islamic Intellectual Culture, 105.
} 
rigeur for Sunnis also". ${ }^{48}$ Al-Shaybī surprisingly skips him and mentions him only once when discussing Kāshif Wa ‘izị’s (910 $\mathrm{H} / 1504)^{49}$ work Rawdat al-Shubadā (the Rose Garden of Martyrs)..$^{50}$ With regard to the minor status of Shi' 1 ism in the Ilkhanid era as well as Kāshānì's training in Suhrawardī Sufism, it is obvious that his Shīìism, as al-Shaybī puts it well, was a Shāmì one; i.e., he shows love and respect to the household of the Prophet without necessarily being a Shi'i Sufi or cursing the first three caliphs and/or companions of the Prophet. ${ }^{51}$ Kāshānī not only benefited from the wide variety of Sufi authorities such as Hasan al-Bașrī, Junayd, Bisțāmī, Fuḍayl b. 'Iyād (d. 187/803) and al-Hallāj (d. 309/922), ${ }^{52}$ but also, as we will observe in the following, utilized the treasury of Shīa hadith to read and interpret Ibn 'Arabî's teachings.

\section{Shī'īitization of Akbarian Mysticism: The Beginning of an Era}

Kāshānī's books ${ }^{53}$ have been discussed in a number of sources. ${ }^{54}$ For our purpose here, I briefly read and analyze his three

\footnotetext{
${ }^{48}$ Lala, Knowing God.

49 Kamāl al-Dīn Husseyn ibn 'Alī Sabziwārī, known as Mawlānā Kāshif Wa iẓ̂̄, Iranian polymath of the Timürid era. He was a Sunni Hanafì 'alim and preacher, whose book Rawdat al-Shubada eventually became one of the most important compilations on Karbalā tragedy.

${ }^{50}$ al-Shaybī, Sufism and Shìism, 275.

51 Al-Shaybî categorizes many Sunni Sufîs and philosophers of the medieval period as such. Another prominent example is Shāh Ni'matullāh Walī (d. 834 H/1430), who clearly stated he was not a Rāfidhī (the enemy of Abū Bakr and other companions), and in fact he was the lover of them and a "comrade of Sunnis" (Shāh Nimatullāh Walī, Dìwān, Vol. 2, 484 in al-Shaybī, Sufism and Shì ‘̀sm, 217-218.

52 Lala, Knowing God, 24.

${ }^{53}$ From among the lengthy list of his books, I only had access to the few following:
} Kāshānī, Sharḥ-i Fusūs al-Ḥikam; Mu'jam Iștilāhạat al-Süfìya (Lexicon of the Sufi Terminology), 'Abd 'Āl Shāhīn (ed.) (Cairo: Dār al-Manār, 1343 H/ 1992). Ta'wilàt Qur'ān Karim (Tafsìri Ibn 'Arabì), translated into Persian: Seyyed Jawād Hāshimī 'Ulyā, Mahnāz Ra' īs Zādih (Tehran: Mawlā, 1393 shamsì).

${ }^{54}$ Here is a short list of works having been done on Kāshānī, on his key texts and his contribution to Akbarian mysticism: Tayefeh, "Concept of Chivalry (Futuwwah) According to 'Abdul Razzāq Kāshānī”; Nasr, Sufi Essays, 116; 'Alāqah, "Murūrì bar Fityān wa Futuwwat Nāmihä’, 295-317; Zarrīnkūb, Dunbāla-yi Justujū dar Tasawnuf-i Iran; Imāmī, "Nigāhī bi Iștilāḥāt-i Ṣūfìya-i Shaykh 'Abdul Razzāq Kāshānī”, 57-80; 'Abdul Ridhā Maẓāhirī, "Ta'līqahāy-i Shī'a bar Fusūs al-Hikam-i Ibn 'Arabī: Shī'a

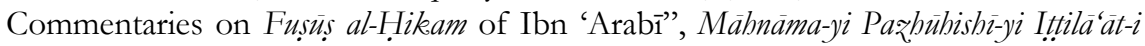
Hikmat wa Ma'rifat, No. 1 (1387 Shamsī/2008), 76-81; Sachiko Murata, The Tao of 
key texts including Ta'milät al-Qur'àn al-Hakim (The Interpretation of the Qur'ān), ${ }^{55}$ Tubfat al-Ikbwān fì Khasäìs al-Fityān (Brethren Trove in Chivalry) and Sharh Hadith al-Haqiqat (Commentary on the Hadith of Truth).

Ta'milät, as scholars such as Lory and Morris have discussed, cannot be regarded a mystical interpretation, because Kāshānī was a shift from Ibn 'Arabî's attitude in the sense that "while the Shaykh alAkbar bases his commentaries on the Qur'ān on a spiritual perception of its metaphysical senses (ḥaqäiq), Kāshānī tries to introduce the verses in a rather simple, pedagogical frame of (philosophical) interpretations". ${ }^{56}$ Furthermore, I will argue in the following that Kāshānì's reading of sainthood, not only in Ta'wilatat, but also in the two other texts, is very close to the Shi' $\mathrm{c}$ understanding of the office of wilaya, which is endorsed by Lory's investigation of the two possible models of sainthood in Ta'wilat as well.

Lory argues that Kāshānī comes up with two types of sainthood: the first type of saint/wali is the one who "tries to attain the truth (haqiqa) by imitating the Prophet. This imitation does not mean simply following the shari $a$ of Muhammad's deeds and conduct, as often occurs in Sunni Islam. It implies that the Prophet's holiness, the prophetic light, is the source and root of all human sainthood and that the Sufi should try to join this source. The second type of saint refers to direct divine inspiration by a journey to God solely by means of divine grace and love". ${ }^{57}$ As we will observe in the following, Kāshānì’s conception of wilāya is similar to its Shî‘̄i reading.

Islam: A Sourcebook on Gender Relationships in Islamic Thought, Foreword by Annemarie Schimmel (New York: State University of New York Press, 1992), 96-99; D. B. Macdonald, "ABD al-Razzak Kashani", The Encyclopedia of Islam, New Edition, Volume I, A-B (Leiden and London: Brill, 1960), 88-90; Pierre Lory, "Eschatology and Hermeneutics in Kāshānī’s Ta'wilàt al-Qur'än", in Annabel Keeler and Sajjad Rizvi (eds.), the Spirit and the Letter: Approaches of the Esoteric Interpretation of the Quran (Oxford: Oxford University Press in Association with the Institute of Ismaili Studies, 2016), 325-343; and the most recent one, Lala, Knowing God.

55 I use the two-volume copy entitled Muhy al-Dīn Ibn 'Arabī, Tafsìr Ibn 'Arabi (Ta'wìlāt 'Abdul Ražàq), edited and annotated by Samīr Muștafā Rabāb (Beirut: Dār al-Ihyyā al-Turāth al-'Arabī, 2000).

56 Lory, "Eschatology and Hermeneutics", 328 \& Morris, "Ibn Arabî and His Interpreters" Part II-A, 33.

57 Lory, "Eschatology and Hermeneutics", 329. 
Pertinent to this is his extensive utilization of the $S$ ir $^{i}$ hadiths, particularly from the first imam, to show how in these initial steps, Akbarian mysticism came to be read and scrutinized from a Shi's perspective. Furthermore, Ali's presence is bold and outstanding throughout the text and is saluted in the Shi' 1 i style of "peace be upon them" ("alayba al-saläm), rather than the Sunni phrase of "God be pleased with him" (radiya Alläh 'anbu). Interpreting the verse twentynine of the sūrah al-Baqarah (the Cow), "He it is Who created for you all that is on the earth. Then He turned to Heaven and fashioned it into seven heavens, and $\mathrm{He}$ is Knower of all things", ${ }^{58}$ Kāshānī maintains that the "sab" a samāwät" indicates the seven levels of the spiritual world (marätib álam-i rawhānìyāt), starting from 'älam almalakūt al-ardiyya wa al-quwwa al-nafsāniyya wa al-jinn down to 'älam alnafs to 'älam al-qalb to 'álam al-'aql to 'älam al-sirr to 'álam al-rawh to 'älam al-khafä. ${ }^{59}$

Obviously, Kāshānī here refers to microcosm, insān, and his description of the journey "means taking the outward expression back to the inner world of the microcosm, and "seven" is a favorite number for enumeration of the lată if (lit. intricacies), for example. After all, the mirajj went through the "seven heavens" in the outside world, so the internal mi räj of the adepts must also go through "seven heavens" on the inside, not outside". "Following his esoteric reading of this verse, Kāshānī brings a hadīth from imàm Ali saying that "salūñ 'an turuq al-samä', fa inni a lam bibà min turaq al-ard" (ask me from the paths of the Heaven because I am more learned about it than the paths of the earth), and maintains that the paths of the Heaven, whose knowledge is in Ali's possession are but [mystical] states and stations (al-ahwäl wa al-maqämät), such as zuhd, tawakkal, ridà, and alike. $^{61}$

\footnotetext{
58 Seyyed Hossein Nasr and Others (eds.), the Study Quran: a New Translation and Commentary (New York: HarperCollins Publishers, 2015), 66.

59 Kamāl al-Dīn 'Abdul Razzāq Kāshānī, Ta'wìlāt al-Qur'ān Hakìm, Samīr Muștafā Rabāb (ed.), Vol. 1 (Beirut: Dār al-Iḥyā al-Turāth al-'Arabī, 2000), 25.

${ }^{60}$ For this part, I am very grateful to Professor William Chittick, who clarified on the issue in my email correspondence with him (dated 10/03/2020), and explained that Kāshānī here points to microcosm and seven heavens (or the allegory of seven stations of spiritual journey), must be understood in light of mi räj.

61 Ibid.
} 
Interpreting verse one-hundred and sixty-eight of the same surah "O mankind! Eat of what is lawful and good on the earth and follow not the footsteps of Satan. Truly he is a manifest enemy unto you", "2 Kāshānī emphasizes the importance of moderation (itidāl) in the body and the soul of the Sufi. Moderation, Kāshānī ascertains, is the fourth shadow, which alongside the shadow of enmity ('adawwat belongs to the world of nafs), of friendship (ulfat belongs to the world of qalb), and of affection (mubabat belongs to the world of rüb), reflects unity (wạ̣dah). ${ }^{63}$ Kāshānī brings another ḥadìth from the same imam stating that "you do not see an ignorant (jähil), unless he goes to two extremes; either exaggeration or understatement (là tara al-jähil illa mufratan aw mufarritan) to support his all-mystical reading of the abovementioned verse..$^{64}$

But probably the most outstanding section of Ta' wilat, which goes beyond narrating hadith and eventually serves to prove the right of the wilaya of Ali and his progenies against the right of the kbilafa of their adversaries, is Kāshānīs interpretation of the verses seventy-two and seventy-three of the Surrah al-Anbiyā" (the Prophets): "And We bestowed upon him Isaac and Jacob as an added gift. And each of them We made righteous. And We made them imams, guiding according to Our Command. And We revealed unto them the doing of good deeds, the performance of prayer, and the giving of alms. And they were worshippers of Us". ${ }^{65}$ He narrates a hadith from the Prophet saying that "Ali and I were two lights (nürayn), which are praised and glorified by God and His angels. And when He created Adam, we were transmitted to his forehead (jibha) and from his forehead to his loins (sulb) until we were transmitted to Seth". 66 Although the badith, known as hadith nürayn (lit. of two lights), is narrated in different ways by the Shì $\imath^{\leftarrow}$ sources, Kāshānīs key point in this text is to prove the right of the khilafa/ wilaya of Ali and his sons as a divine one and their office as divinely assigned.

Clarifying the term sadaqa (almsgiving/charity) and the philosophy behind it in verses twelve and thirteen of the Sürab alMujädilab (She Who Disputes): "O you who believe! When you

${ }^{62}$ Nasr and Others (eds.), the Study Quran, 80.

${ }^{63}$ Kāshānī, Ta'wilàt al-Qur'àn, Vol. 1, 64.

64 Ibid., Vol. 1, 65.

${ }^{65}$ Nasr and Others (eds.), the Study Quran, 1471.

${ }^{66} \mathrm{Kā}$ shānī, Ta'wìlāt al-Qur'ān, Vol. 2, 45. 
converse in secret with the Messenger, offer charity before your secret converse. That is better for you and purer. But if you do not find [the means], truly God is Forgiving, Merciful. Are you apprehensive about offering charity before your secret converse? If you do not do so and God relents unto you, then perform the prayer, give the alms, and obey God and His Messenger. God is Aware of whatsoever you do", ${ }^{67}$ in which believers are recommended to give charity before they want to converse with the Prophet, Kāshānī explains that the first and foremost to do to approach the Prophet and eventually reach spiritual attachment to him is to alienate (insiläkh) self from any worldly connection.

For Kāshānī, obviously, this is the real meaning of sadaqa. When the station (maqaim) of tajrid is achieved, the believer will share the Prophet's divine secrets. In the following, Kāshānī mentions a statement from the second caliph, 'Umar b. Khattāb (d. 23 H/644), where Ali is praised for his sole and unique status due to giving charity before conversing with the Prophet and instead of benefitting from three things that 'Umar (and obviously no one else) never had: marriage with Fatemeh, the endowment of the flag of Khaybar and Ayat al-Najwà (al-Najwā or al-Munäjät verse). ${ }^{68}$ In all probability, Ta'milat is the first text among similar works wherein Shí'a ḥadiths are frequently mentioned and imäms are introduced as role models, ideal exemplars, of a mystical lifestyle. Kāshānı̀'s initiative in reading the teachings of Ibn 'Arabī, of which he was a full defender and disseminator, in the shadow of the Shi' a hadiths, paved the way for figures such as the aforementioned Sayyid Haydar Āmuli to claim that Sufism is Shī ‘̄sm and vice versa. ${ }^{69}$ Furthermore, Āmulī’s inspiration from Kāshānī is well-documented. ${ }^{70}$

Tuhfat al-Ikhwàn fi Khasäis al-Fityan is written on the request (order?) of his shaykh, al-Shaykh al-Kabir, Abū Hafṣ 'Umar b. 'Abd Allāh Shahāb al-Dīn Suhrawardī (d. 620-632? H/1234), the

\footnotetext{
${ }^{67}$ Nasr and Others (eds.), the Study Quran, 2463.

${ }^{68}$ Kāshānī, Ta'mìlāt al-Qur'ān, Vol. 2, 326.

${ }^{69}$ Haydar Āmulī, Jämi' al-Asrär wa Manba' al-Anwär (the Comprehensive of Mysteries and the Source of Lights), translated into Persian by Muhammad Rị̣ā Jūzì (Tehran: Hermes, 1391).

70 This inspiration was so great that it encouraged Âmulī to write "a fervent panegyric”. See Lala, Knowing God, 23, footnote 120, on Kāshānī.
} 
Suhrawardi qutb of the time..$^{71}$ At the beginning of the text, Ali is praised as the "generous chivalrous of the Arab" and "the everconqueror Lion of God". ${ }^{72}$ Defining chivalry as the appearance of the natural disposition (fatrah) via its attributes and faculties ... in order to actualize the potentials of the natural disposition and prepare it for perfection (kamāl), ${ }^{73}$ because perfection is a requirement for the sincere and truthful Abrahamic fatrah, Kāshānī argues that chivalry and achieving perfection are a foundation for wilaya, which only belongs to Ali. ${ }^{74}$ It belongs to him because his natural disposition is at its paramount of perfection because the appearance of wilaya in a servant causes the perfection of chivalry in him. ${ }^{75}$ Therefore, he is called fatā (chivalrous), because he has used his isti däd (preparedness) to actualize his potentials. ${ }^{76}$

Abraham is the primal point of wilaya (awwal nuqta), it's beginning (mufattih) and the first hanif (monotheist), though the culmination, the qutb (pillar) of wilaya is Ali, because he rectifies every

\footnotetext{
${ }^{71}$ Kāshānī, Sharḅ-i Fușūs al-Hikeam, 11.

72 Ibid.

${ }^{73}$ For a long time, and until Ibn 'Arabī, the popular belief among the mystics was that God is manifested in conformity with the preparedness (isti dad d) of the servant, but according to Ibn 'Arabī and his students including Kāshānī, this preparedness of the servant, isti'dad, "is rather the servant's preparedness to conform to a particular form of God's phenomenal appearance. Indeed, this isti'däd is given by God to His servant [italic is in the text] (Ronald L. Nettler, Sufi Metaphysics and Qur'anic Prophets: Ibn Arabi's Thought and Method in the Fusus al-Hikam (Cambridge: the Islamic Texts Society, 2003), 124-125. Thus, when this preparedness comes to the heart, the heart sees Him in the form in which He is revealed to it. Therefore, the heart of the 'arif is the only thing that sees God in everything and worships him in the infinite shapes of His manifestations (Masataka Takeshita, "Ibn Arabi's Theory of the Perfect Man and Its Place in the History of Islamic Thought" (Ph.D. Thesis-University of Chicago, 1986), 117-118. Furthermore, according to Ibn 'Arabì. A mystic should use her/his isti'dād to actualize things in the external world. Kāshānī, as the true student of this school and its defender, uses this new conception of isti'dad and ties it to fatrah and to futumwa, as the actualization of the hidden attributes and faculties integral of fatrah. Fata is the one who has been successful is nurturing, or rather, actualizing these intact faculties. In this worldview, servant is not passive in receiving emanation (fayd) in his quest for perfection. She/he has agency and subjectivity.

74 Ibid., 13-14.

${ }^{75}$ Ibid., 15.

${ }^{76}$ Ibid., 17.
} 
distortion or imperfection $\left(i^{i}\right.$ wajaj $) .{ }^{77}$ Ali occupies a far higher position than Abraham, because Ali's futumwa is about renouncing Self, and not just a son, to deity and has been inherited by his progenies until his wilaya finally rests in his son al-Mahdi, who is the seal of wilaya (khätam) and his status being equal to the status of the sealing of the nubunwa of the Prophet. ${ }^{78}$ To conclude, Ali's wilāya is equal to the Prophet's nubuwwa, while Abraham's wilaya is equivalent to Adam's nubuwna ${ }^{79}$ In the following, Kāshānī lists the virtues of chivalry as well as its four pillars, including chastity ('iffat), courage (shujä'at), wisdom (bikmat), and justice ('idalat), which are all put together in the personality of Ali. ${ }^{80}$

Dagli is right when maintains that the Book of Chivalry is written "in keeping with his background in the Suhrawardiyyah order and its emphasis on futumwab", though it is not contradictory to assume that for Kāshānī, the imàms ought to be modeled as the prototype of chivalry, fraternity, and sincere servitude. Narrating a

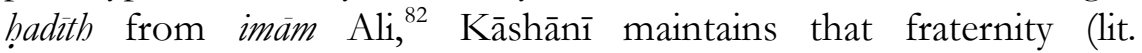
ikhwaniyya) is one of the most significant dimensions of futuwwa and "its foundation and fundamental principle", 83 because the love between people is dependent on fraternity. Since chivalry is the best and most beautiful lifestyle (lit. aḥsan tarä'iq al-nās wa ajmalahä) man

\footnotetext{
77 Ibid., 16.

78 Ibid.

79 Ibid.

${ }^{80}$ Kāshānì's discussion of the four pillars of futumwa is in fact a Platonic subject, which has been an inseparable part of Islamic philosophy and ethics since the beginning. We know that the main concern of Plato in the book Republic was justice in the soul and in the city, the polis, and it will be actualized when balance or harmony between the three miniature personalities (i.e., three parts of the soul including courage, wisdom and moderation) is realized. When this task is done, justice will be achieved (A. C. Grayling, (ed.), Philosophy 1: A Guide through the Subject (Oxford: Oxford University Press, 2004), 370-371). The only difference is that for Kāshānī, justice is not singled out as the main virtue, or the climax of the three miniature virtues, it is just one of them. Ibid., 18-51.

${ }^{81}$ Dagli, Ibn 'Arabi and Islamic Intellectual Culture, 105.

82 A'jaza al-nās man 'ajaza an iktisäb al-ikhwān, wa a'jaza min-bu man dhuyyi'a min zafar-i bih-i minhum. [The most incapable of Man is the one who is disabled to earn friendship and even more incapable of him is the one who spoils the assistance of his brothers]. See 'Abdul Razzāq Kāshānī, Rasāill-i Falsafì wa 'Irfānì (Philosophical and Mystical Treatises) (n.d, n.p.), 548, Tayefeh, "Concept of Chivalry (Futumwah)”, 288.

83 Kāshānī, Sharḅ-i Fusūss al-Hikeam, 36.
} 
can adopt, Ali is the qutb and imàm of all chivalrous. ${ }^{84}$ Kāshānìs innovation is not just his abundant use of narrations from the first and the fourth imams, ${ }^{85}$ which is most probably the first of its kind among Iranian Sufis, but also his contrast to Ibn 'Arabî's reading of the virtue of chivalry, which is more egalitarian and gender-neutral. Sa'diyya Shaikh shows how some Sufis, including Ibn 'Arabī, used futuwwa and/or fityan "to describe a number of exemplary female Sufi practitioners", but Kāshānîs description, on the other hand, is allmasculine and patrimonialistic.

The last text which is our concern here is Sharb Hadith alHaqiqat, which along with Tubfat is published in a collection entitled Ádāb ul-Ṭariqah wa Asrär ul-Haquiqah fì Rasàill al-Shaykh 'Abdul Razzōq al-Qamishani (the Ethics of the Path and the Secrets of the Truth in the Treatises of Shaykh 'Abd al-Razzāq al-Qāmishānī). The text revolves around Kāshānì's reading of the famous hadìth of imām Ali, when his loyal friend and disciple, Kumayl b. Ziyād an-Nakha'ī (d. 82$83 \mathrm{H} / 702$ ) asks him about the meaning of the Truth. The hadith is not documented in any hadith compilation, but its mystical connotations have been narrated by several Sufi authorities and is commented upon by many 'arifs. Interestingly, as much as the clarification of the meaning of wilāya is important for Kāshānī, the meaning of the main problem of this hadith, i.e., haqiqah, is not. Ali is the holder of the station (maqām) of completion (lit. takmī), endurance (lit. istiqāmat, i.e., or the backbone of strength and power) and obedience (tamkin), while Kumayl's status is that of the heart (lit. maqäm-i qalb) and quest (lit. talab).

But why is Ali's status that of completion? Because it contains sirr (secret) and Ali is its cognizant ('ärif), and therefore maqäm al-sirr is the same as maqam al-wilaya. Defining wilaya as the status of selfannihilation (fană), Kāshānī argues that Kumayl was only at the beginning of a path which eventually ends in Ali, who has stood at the peak of it. However, like any other beginner, Kumayl must use his isti'däd should he want to actualize his potentials and realize his ideal,

\footnotetext{
${ }^{84}$ Ibid.

${ }^{85}$ Was Kāshānī familiar with Nahj ul-Baläghah and Sahïfat al-Sajjäadiyya of the fourth imàm? In all probability yes, because the ethics of both treasuries is the spirit of Tubfa.

86 Sa'diyya Shaikh, Sufi Narratives of Intimacy: Ibn 'Arabi, Gender and Sexuality (Chapel Hill: The University of North Carolina Press, 2012), 52.
} 
i.e., the status of wilāya, in the real world. ${ }^{87}$ Kāshānî̀s choice of this Shía hadith itself indicates his devotion to the first imam and his teachings, because maqaim al-sirr, according to another famous hadith, is but Imämì Shììsm.

\section{Concluding Remarks}

Kāshānī’s role in disseminating, formalizing, and systematizing the teachings of Ibn 'Arabī, and particularly the challenging terrain of his technical terms, is undeniable. ${ }^{89}$ Based on a master-disciple relationship, he obtained his education from Mu'ayyid al-Dīn Jandī, who, along with Sa īid al-Dīn Faraghānī (both d. 700/1300), was an important student of Șadr al-Dīn al-Qūnawì. Qūnawìs place as the first expositor and spokesman of Ibn 'Arabī is well-attested. Furthermore, he had a profound impact on his famous student, Sharaf al-Dīn Dāwūd Qayṣarī (d. 751 H/1350), another influential commentator of the Fususs, entitled Sharḅ-i Fususs al-Hikam (the Commentary on Fusüs al-Hikam). These last two figures' commentaries on the Fususs "have been studied perhaps more than any others by serious seekers of knowledge up to modern times". ${ }^{90}$ So, we have a one-hundred-year direct and uninterrupted line of teaching and training, which contributed to the robust tree of the theoretical mysticism of Ibn 'Arabì in the eastern part of the Muslim world. This specific line, revolving around Kāshānī and his student, has continued to exist up to the present time, when we see how they

${ }^{87}$ Kāshānī, Sharhbi Fusūụ al-Hikeam, 119-123.

${ }^{88} \mathrm{~K} a \bar{s} h \bar{a} n \overline{1}$, as I mentioned earlier in this paper, was well-aware of the Shí' a hadith sources, and his analysis of the status of wilaya and its nexus to sirr, is based on a famous ḥadith by the sixth imäm, Ja'far al-Ṣādiq which is related by Abū Ja'far Moḥammad b. al-Ḥasan b. Farrukh al-Ṣaffār al-Qumī in Basāìr al-Darajät fì Fazāìl Al-i Mubammad (Clear Proofs in the Sciences of the Household of the Prophet and on Whatever is Designated to Them by God), in which the imàm says "innà amrinā sirr o fi sirr, wa sirr o mustatar, wa sirr u là yafídu illà sirr, wa sir 'alà sirr wa sirr o muqannā bil sirr'. Abū Ja'far Muḥammad b. al-Hasan b. Farrukh al-Ṣaffār al-Qumī, Basāìr alDarajāt fì 'Ulüm-i Alli Muhammad wa Mà Khașsabum ul-llāh Bihì (Insights into the Degrees, on the Knowledge of the Family of Muhammad and That with which Allah Endowed Them), Mīrzā Muhssin Kūchih Bāghī Tabrīzī (ed.) (Qum: Manshūrāt-i Maktabat Ayatollah al-'Uzma Mar'ashī Najafì, 1404 H), 28. According to this reading, wali is a treasurer (khäzin) of whatever God has created in the cosmos, but specifically a treasurer of His sirr. Ibid.

${ }^{89}$ Lala, Knowing God, 31.

90 Chittick, "The Five Divine Presences”, 107. 
considerably shape the metaphysical outlook of contemporary individuals such as Rūhullāh Khomeini (d. 1368 H/1989). ${ }^{91}$

Kāshānī also extensively wrote about all the elements of Akbarian mysticism, from wabdat al-wujüd to the Perfect Man (when he discusses chivalry), and to the Five Divine Presences (al-ḩadarät alilähiyat al-khams). However, as far as we are concerned, his innovation rests in benefiting from the Shī'a authorities to both elucidate the key terms of Ibn 'Arabî's mysticism, such as tajallil' (lit. theophany), wilaya and Khatm al-wilaya, and to shed light on the intricacies of his teachings; because for him there was no contrast between these two and the former fully supported the latter. Even when he is not discussing the central Akbarian terms, he still refers to the Shi' a authorities and cites the imäms as the role models, the ideal exemplar, the wali, and the only owner of the true knowledge (ma'rifa). For him, the seals of the prophets and of the awliy $\bar{a}$ are the rightful owners of ilm, and other prophets and walis gain light from their mishkät (lamp), and the seal of the Mohammedan wilaya is but al-Mahdi from the household of the Prophet, ${ }^{93}$ who is the "mine of the divine knowledge" and shares the name, title and characteristics of the Prophet. ${ }^{94}$

In the case of wilaya and khatm al-wilaya, as well as that of futuwwa, he had a divergent outlook from Ibn 'Arabī, which eventually came to be regarded as the predominant reading among Shi'a commentators in subsequent generations. Thanks to Haydar Âmulī and his Jämi' al-Asrär wa Manba' al-Anwär (the Comprehensive of Mysteries and the Source of Lights), which indeed is the culmination

91 I have discussed this tradition and its continuation to our time elsewhere. For more information see Leila Chamankhah, The Conceptualization of Guardianship in Iranian Intellectual History (1800-1989): Reading Ibn 'Arabi's Theory of Wilaya in the Shi'a World, Chapter 5 (Cham: Palgrave Macmillan, 2019), 171-200.

92 The hadīth of imàm Ali stating that "Basîrun idh là mañūra ilayb-i min al-khalqib" (lit. He does not need any manifestation to reflect Himself in) is used to both explain the meaning of this term and why Deity does not need to see Himself and His face in anything because $\mathrm{He}$ is Basir (lit. Insightful) and therefore selfexplanatory without need for a mirror to reflect Himself. See Kāshānī, Sharḥ-i Fusūs al-Hikam. Kāshānī, in this text, uses Shī'a hadìth in this text pervasively and when brings a hadith from Imām Ali praises him as "Karram Alläh wajhab" (lit. may God bless his face), which leaves no doubt that Kāshānī, as mentioned above, is a Sunni scholar in the Syrian definition.

${ }^{93}$ Kāshānī, Sharḥ-i Fusūus al-Ḥikeam, 126-127.

94 Ibid., 127. 
of such a union between Sufism and Shīism. Pertinent to this, is Kāshānì's conception of buwiyyya, which as Ismail Lala discusses, contradicts that of his master too. ${ }^{95}$ Given this, Kāshānī was definitely more than a commentator and student of the school of Ibn 'Arabī and should be treated as an independent and innovative mystic who, by offering different readings of the main teachings of his master, left his imprint on Akbarian mysticism indefinitely.

\section{References}

"Alāqah, Fātẹemeh. "Murūrì bar Fityān wa Futuwwat Nāmihā: A Review on Chivalrous and Books of Chivalry", Farhang, No. 25-26, Spring and Summer 1377 Shamsī/1999.

Amir-Moezzi, Mohammad Ali. The Divine Guide in Early Shiism: the Sources of Esotericism in Islam, translated into English by David Streight. New York: State University of New York Press, 1994. ----. The Spirituality of Shii Islam: Beliefs and Practices. London and New York: I. B. Tauris Publisher, 2011.

Amitai-Preiss, Reuven. "Sufis and Shamans: Some Remarks on the Islamization of the Monglos in the Ilkhanate", Journal of the Economic and Social History of the Orient (JESHO), Leiden, Vol. 42, No. 1, 1999.

Āmulī, Haydar. Jämi' al-Asrār wa Manba' al-Anwār (the Comprehensive of Mysteries and the Source of Lights), translated into Persian by Muhammad Riḍā Jūzī. Tehran: Hermes, 1391.

'Arabī, Muhy al-Dīn Ibn. Tafsìr Ibn 'Arabì (Ta'wìlät 'Abdul Razzāq), edited and annotated by Samīr Muṣtafā Rabāb. Beirut: Dār alIhyā al-Turāth al-'Arabī, 2000.

Chamankhah, Leila. The Conceptualization of Guardianship in Iranian Intellectual History (1800-1989): Reading Ibn 'Arabi's Theory of Wilaya in the Shi' World, Chapter 5. Cham: Palgrave Macmillan, 2019.

\footnotetext{
95 As Lala ascertains, bumiyya plays a central role in the "Sufis' semantic Weltanschauung and often incorporates other terms within it (such as ananiyya whose existence in implied by humiyya ...)". Lala, Knowing God, 29. It also plays an important role in the mystics' account of God, though it is defined differently by Ibn 'Arabī and Kāshānī. For Ibn 'Arabī, buwìyya denotes God's absolute unknowability, "a state in which He is truly non-manifest", but Kāshānī "deploys it principally to connote the second emanatory stage in which there is a prefiguring of creation within the divine consciousness". Lala, Knowing God, 64-179.
} 
Chittick, William. "The Five Divine Presences: From al-Qūnawī to alQayșarı’”, The Muslim World, Vol 72, Issue 2, April 1982.

Dagli, Caner K. Ibn 'Arabi and Islamic Intellectual Culture: from Mysticism to Philosophy. London and New York: Routledge Sufi Series, 2016.

Dāwarī, Maḥmūd Taqū Zādih. Sunat-i 'Azādārì wa Manqibat Khānī dar Tärikh-i Shía-yi Emämiya (The Lamentation Tradition and Mourning in the History of the Imāmi Shìism). Qum: Shī'a Shināsī, 1386 Shamsi.

Ebstein, Michael. "The Organs of God: Hadīth al-Nawāfil in Classical Islamic Mysticism", Journal of the American Oriental Society, Vol. 138, No. 2, 2018.

Grayling, A. C. (ed.). Philosophy 1: A Guide through the Subject. Oxford: Oxford University Press, 2004.

Imāmī, Al̄̄ Ashraf. "Nigāhī bi Ișțilāhāt-i Șūfĩya-i Shaykh 'Abdul Razzāq Kāshānī: A Glimpse at Kāshānì̀s Lexicon of the Sufi Terminology", Majalla-yi Dānishkada-yi 'Ulüm-i Insānì, No. 1, Spring 1381 Shamsī/2001.

Karamustafa, Ahmet T. Sufism: the Formative Period. Edinburgh: Edinburgh University Press, 2007).

Kāshānī, 'Abdul Razzāq. Rasāìl-i Falsafì wa 'Irfānì (Philosophical and Mystical Treatises). n.d, n.p.

Kāshānī, Kamāl al-Dīn 'Abdul Razzāq. Sharḥ-i Fusūṣ al-Hikam (Commentary on the Fusūss al-Hikam) Majīd Hādīzādih (ed.) (Tehran: Anjuman-i Āthār wa Mafākhir-i Farhangī, 2004.

-----. Sharh-i Fusụș al-Ḥikam, Majīd Hādīzādih (ed.). Tehran: Anjumani Āthār wa Mafākhir-i Farhangī, 1383 shamsì.

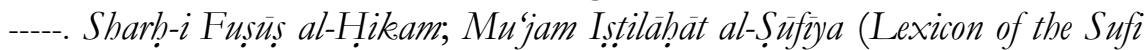
Terminology), 'Abd 'Āl Shāhīn (ed.). Cairo: Dār al-Manār, 1343 $\mathrm{H} / 1992$.

----. Ta'wñlāt al-Qur'àn Hakim, Samīr Muștafā Rabāb (ed), Vol. 1. Beirut: Dār al-Ihyyā al-Turāth al-'Arabī, 2000.

----. Ta'wilät Qur'än Karim (Tafsìr-i Ibn 'Arabi), translated into Persian: Seyyed Jawād Hāshimī 'Ulyā, Mahnāz Ra'īs Zādih. Tehran: Mawlā, 1393 shamsì.

Lala, Ismail. Knowing God: Ibn 'Arabì and 'Abd al-Ražāq al-Qāshānìs Metaphysics of the Divine. Leiden and Boston: 2019. 
Lory, Pierre. "Eschatology and Hermeneutics in Kāshānì’s Ta'wìlāt alQur'än", in Annabel Keeler and Sajjad Rizvi (eds.), the Spirit and the Letter: Approaches of the Esoteric Interpretation of the Quran. Oxford: Oxford University Press in Association with the Institute of Ismaili Studies, 2016.

Macdonald, D. B. “ABD al-Razzak Kashani”, The Encyclopedia of Islam, New Edition, Volume I, A-B. Leiden and London: Brill, 1960. Masterton, Rebecca. "A Comparative Exploration of the Spiritual Authority of the Amliy $\bar{a}$ ' in the Shic and Sufi Traditions", American Journal of Islamic Social Sciences, Vol. 32, No. 1, 2015.

Mazāhirī, 'Abdul Ridhā. Ta 'līqahāy-i Shī'a bar Fuṣụs al-Hịkam-i Ibn 'Arabī (Shī'a Commentaries on Fusūs al-Hikam of Ibn 'Arabì', Māhnāma-yi Pą̧hūbishi-yi Iț̣ilāát-i Hikemat wa Ma'rifat, No. 1, 1387 Shamsī/2008.

Momen, Moojan. Shi'i Islam: A Beginner's Guide. London: Oneworld, 2016.

Morris, James W. "Ibn Arabî and His Interpreters, Part II-A", Journal of American Oriental Society (JAOS), Vol. 106, 1986.

----. "Ibn Arabî and His Interpreters, Part II-B", Journal of American Oriental Society (JAOS), Vol. 107, 1987.

Murata, Sachiko. The Tao of Islam: A Sourcebook on Gender Relationships in Islamic Thought, Foreword by Annemarie Schimmel. New York: State University of New York Press, 1992.

Nasr, Seyyed Hossein and Others (eds.). the Study Quran: a New Translation and Commentary. New York: HarperCollins Publishers, 2015.

Nasr, Seyyed Hossein. Sufi Essays. New York: Schocken Books, 1977.

Nettler, Ronald L. Sufi Metaphysics and Qur'anic Prophets: Ibn Arabi's Thought and Method in the Fusus al-Hikam. Cambridge: the Islamic Texts Society, 2003.

Pāzūkī, Shahrām. Jāmi al-Asrār: Jāmi bayn Tasawwuf wa Tashayu', in Muṣtafā Azmāyish (ed.), 'Irfän-i Iran (Iranian Mysticism), No. 7, Tehran: Haqīqat Publication, , 1379 shamsi.

Pfeiffer, Judith. "Conversion Versions: Sultan Öljeytü’s Conversion to Shi'ism (709/1309) in Muslim Narrative Sources", Mongolian Studies, Vol. 22, 1999.

Radtke, Bernd. "Between Projection and Suppression: Some Considerations Concerning the Study of Sufism", in Frederick De Jong (ed.), Shi'a Islam, Sects and Sufism, Historical Dimensions, 
Religious Practice, and Methodological Considerations. Utrecht: Publications of the M. Th. Houtsma Stichting, 1992.

Shabistarī, Maḥmūd b. 'Abd al-Karìm. Gulshan-i Rā̃ (the Rose Garden of Mystery), Muḥammad Ḥimāṣìyān (ed.). Kerman: Khadamāt-i Farhangi-ya Kerman, 2003.

Shaikh, Sa'diyya. Sufi Narratives of Intimacy: Ibn 'Arabi, Gender and Sexuality. Chapel Hill: The University of North Carolina Press, 2012.

Shaybī (al), Kāmil Muṣtafā. al-Ṣilah bayn al-Tasawwuf wa al-Tashayu', 2 volumes, $3^{\text {rd }}$ edition. Beirut: Dār al-Andalus, 1982.

----. Sufism and Shiissm. Surbiton: LAAM, 1991.

Takeshita, Masataka. "Ibn Arabi's Theory of the Perfect Man and Its Place in the History of Islamic Thought". Ph.D. Thesis-University of Chicago, 1986.

Tayefeh, Fatemeh. "Concept of Chivalry (Futumwah) According to 'Abdul Razzāq Kāshānī: Analysis on His Tuhfat al-Ikhwān fì Khasaìs al-Fityan (Brethren Trove in Chivalry). Academy of Islamic Studies, University of Malaya, 2015.

Tucker, William F. The Kufan Ghulat and Millenarian (Mabdist) Movements in Mongol-Turkmen Iran, in Unity in Diversity: Mysticism, Messianism, and the Construction of Religious Authority in Islam, Orkhan MirKasimov (ed.). Leiden: Brill, 2014.

Zarrīnkūb, 'Abdul Hussein. Dunbāla-yi Justujū dar Tașawwufi Iran (Sequel to Inquiries into Persian Sufism), $5^{\text {th }}$ edition. Tehran: Amir Kabīr Publication, 2001. 